\title{
FALLING LABOR INCOME INEQUALITY IN KOREA'S ECONOMIC GROWTH: PATTERNS AND UNDERLYING CAUSES
}

\author{
Gary S. Fields \\ Cornell University \\ Gyeongjoon Yoo \\ Korea Development Institute
}

Over the last twenty-five years, the economy of the Republic of Korea achieved a remarkable growth rate of 7 percent per year in real per capita income, causing it to be labeled, justifiably, as a "miracle economy." This exceptional economic growth has been accompanied by an even more exceptional fall in labor income inequality. Using a newly-developed methodology, we use data from Korea's Occupational Wage Surveys to quantify the importance of various factors that have contributed to the fall in labor income inequality in Korea. We find the most important factors explaining the level of income inequality are job tenure, gender, years of education, and occupation, while those that are most important in explaining the change in income inequality are years of education, industry, occupation, and potential experience.

\section{Introduction}

Over the last twenty-five years, the economy of the Republic of Korea (hereafter simply "Korea") achieved a remarkable growth rate of 7 percent per year in real per capita income. This has caused Korea to be labeled, justifiably, as a "miracle economy." "This exceptional economic growth has been accompanied by an even more exceptional fall in labor income inequality, which is documented in detail in Section 2. Korea's labor income inequality, as measured by the Gini coefficient, fell by eleven Gini points between 1976 and 1993 - a 27 percent decline. The current level of labor income inequality in Korea is comparable to that now found in Taiwan, which has one of the world's most equal income distributions. To put Korea's falling labor income inequality in perspective, per person income inequality remained constant in Taiwan from 1980 to the mid- 1990s (Chu, 1997; Schultz, 1999), as did the inequality of individual labor earnings (Fields and Mitchell, 1999).

The research reported in this paper takes a first step toward understanding what accounts for Korea's falling labor income inequality in the course of its rapid economic growth. The plan is as follows.

Section 2 reviews the most important previous contributions to the literature on changing income inequality in Korea, describes the data set to be used in the present study (Korea's Occupational Wage Survey), presents the year-by-year time series which shows steadily-falling labor income inequality, and introduces some of the factors that played a role during this period. 
Section 3 then presents the methodology for quantifying the importance of these various factors. The results of this methodology, presented in Section 4, show that the most important factors accounting for the level of income inequality in Korea are job tenure, gender, years of education, and occupation, while those that are most important in accounting for the change in income inequality are years of education, industry, occupation, and potential experience. Section 5 concludes.

To preview what follows, we are able in this study to quantify effects which hitherto could only be guessed at. For instance, Kim and Topel (1995) attribute the falling wage inequality in Korea to a more equal distribution of education, which reduced wage inequality directly and also brought about adjustments in the wage structure because of changes in relative supplies of well-educated compared to less-educated labor. Our results below support this conclusion, but we can also go one step further. Kim and Topel write (p. 261): "How much of the overall narrowing of the wage distribution is caused by improvements in overall human capital and consequent substitution effects? We are unable to say, but these results suggest that the effects may be quite large." Our research answers this question by disaggregating the equalizing effect of education into components reflecting a more equal distribution of years of schooling, a falling educational wage premium, and a changing correlation between education and wage.

We turn now to the data.

\section{Changes in Inequality and Over Time}

\section{A. The Data Set Used}

Since 1971, the Korean government has conducted an Occupational Wage Survey. In this paper, we use the surveys up to 1993, the latest year available when this study began.

The survey first selects companies from a list of companies with 10 or more employees. The survey covers all workers in the selected companies with 10-99 employees, 70 percent of those in companies with 100-299 employees, 50 percent of those in companies with 300-499 employees, and (depending on the year) up to 50 percent of those in companies with 500 or more employees. All industries and regions are included except for government offices, army and police, and educational institutions. The OWS covers about 60 percent of total employees and about 7 percent of total establishments.

For this analysis, we selected a random 10 percent of workers covered by the OWS, producing a working sample of between 400,000 and 500,000 workers per year. The inequality data reported below use the OWS data tapes for all years between 1971 and 1993 except for 1975 and 1977, for which the surveys are missing.

The labor income variable used in this study is the worker's wage and salary income, including base salary, overtime pay, and bonuses. The latter two are increasingly important components of income in the Korean context. 
The main advantage of the OWS is that it permits calculations of year-by year changes (except for the missing years). The OWS is not without its limitations, however. By the nature of the sampling design, workers in small companies, the self-employed, and the unemployed are excluded. Furthermore, the OWS gathered information on only the labor earnings of sampled workers; thus, information is not available on the individual's other income sources or on the incomes of other family members. ${ }^{2}$ These features of the data set should be borne in mind in what follows.

\section{B. Previous Calculations of Changing Income Inequality in Korea}

By now, a large number of studies have presented data on income inequality in Korea. For data reasons, inequality estimates are presented only for selected years. ${ }^{3}$ Three quite different patterns appear in these studies: (i) increasing inequality in the work of Kim and Ahn, (ii) a Kuznets-type inverted-U curve, with inequality first rising and then falling, in the work of Choo, and (iii) falling inequality in the work of Kim and Topel. Thus, the fundamental question of whether Korea's economic growth has been equalizing or disequalizing has not yet been settled.

\section{Our Findings on Inequality in Korea Using the OWS}

Our analysis of the annual OWS data provides the first opportunity for researchers to look at inequality year-by-year in Korea on a national basis. ${ }^{4}$ It should be borne in mind that what is being measured with the OWS is the inequality of labor income only.

Our calculations produce the same conclusion as Kim and Topel's: labor incomes in Korea have become much more equally distributed over time. Comparisons of Gini coefficients and Lorenz curves support this conclusion.

The Gini coefficients are presented in Figure 1. These data show that the Gini coefficient fell in almost every year. Furthermore, the Gini coefficient dropped by eleven Gini points in seventeen years, which is quite large - the same order of magnitude as the difference between the inequality level of the average East Asian country as compared with the average Latin American country. ${ }^{5}$

The conclusion that inequality fell is strengthened by Lorenz curve comparisons. We divided the earners into ten decile groups and compared the Lorenz curves of labor earnings for successive years. (See Figure 2 and Table 1.) These data show successive Lorenz-improvements since 1976, i.e., each Lorenz curve lies closer to the forty-live degree line than the preceding one. $^{6}$

The analysis that follows aims to explain in an accounting sense which factors contributed how much to the large fall in labor income inequality in Korea. 


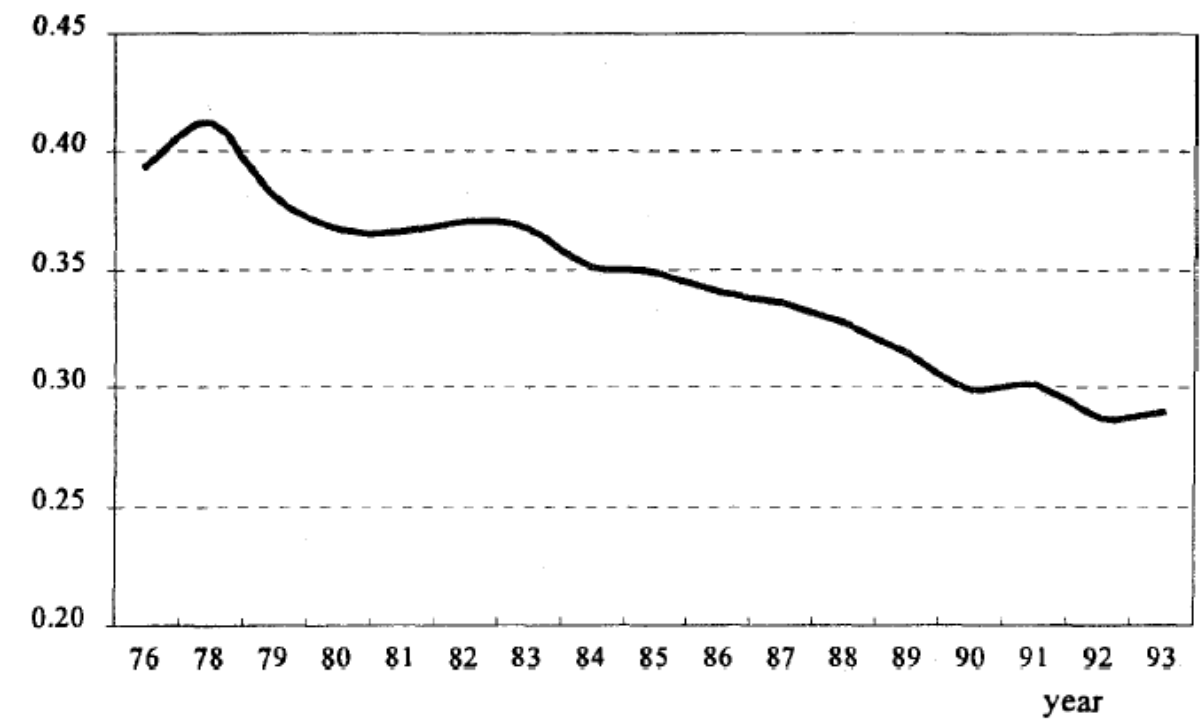

Figure 1: Gini Coefficients of Labor Income Inequality in Korea, 1976-93 Note: there was no OWS in 1977

Source: Authors' calculations from OWS tapes.

\section{Determining the Causes of Changing Labor Income Inequality in Korea}

Some changes in the structure of labor incomes are well-documented and generallyaccepted in the literature on Korean labor markets. Published data show that gross differentials in labor incomes have narrowed by worker characteristics and have widened by employer characteristics. In particular (Table 2):

- The differences in labor incomes between educational groups have decreased (Ministry of Labor, various years; Kim and Topel, 1995; Choi, 1996).

- Wage and salary differentials by occupation have diminished (National Statistical Office, various years; Choo, 1993).

- Gender differences in labor incomes have narrowed (Ministry of Labor, various years; Bai and Cho, 1995; Rodgers, 1998).

- The firm size differential has widened (Ministry of Labor, various years; Kim and Yoo, 1996).

- The union wage effect has increased (unpublished calculations by the authors from OWS tapes).

Only the differentials that narrowed would be expected to contribute positively to the fall in income inequality in Korea. This is, however, only suggestive, for two reasons. First, these earnings differentials are not standardized for other changes. For instance, did gender differences in labor earnings fall, because (i) education is a key determinant of earnings, and in recent years, Korean women acquired more education than did Korean men; (ii) at any given level of education, the male-female earnings differential fell, or (iii) both? Second, no quantitative measure is presented indicating the relative importance of different factors. For example, how 
important was the narrowing of educational differentials relative to the narrowing of gender differentials?

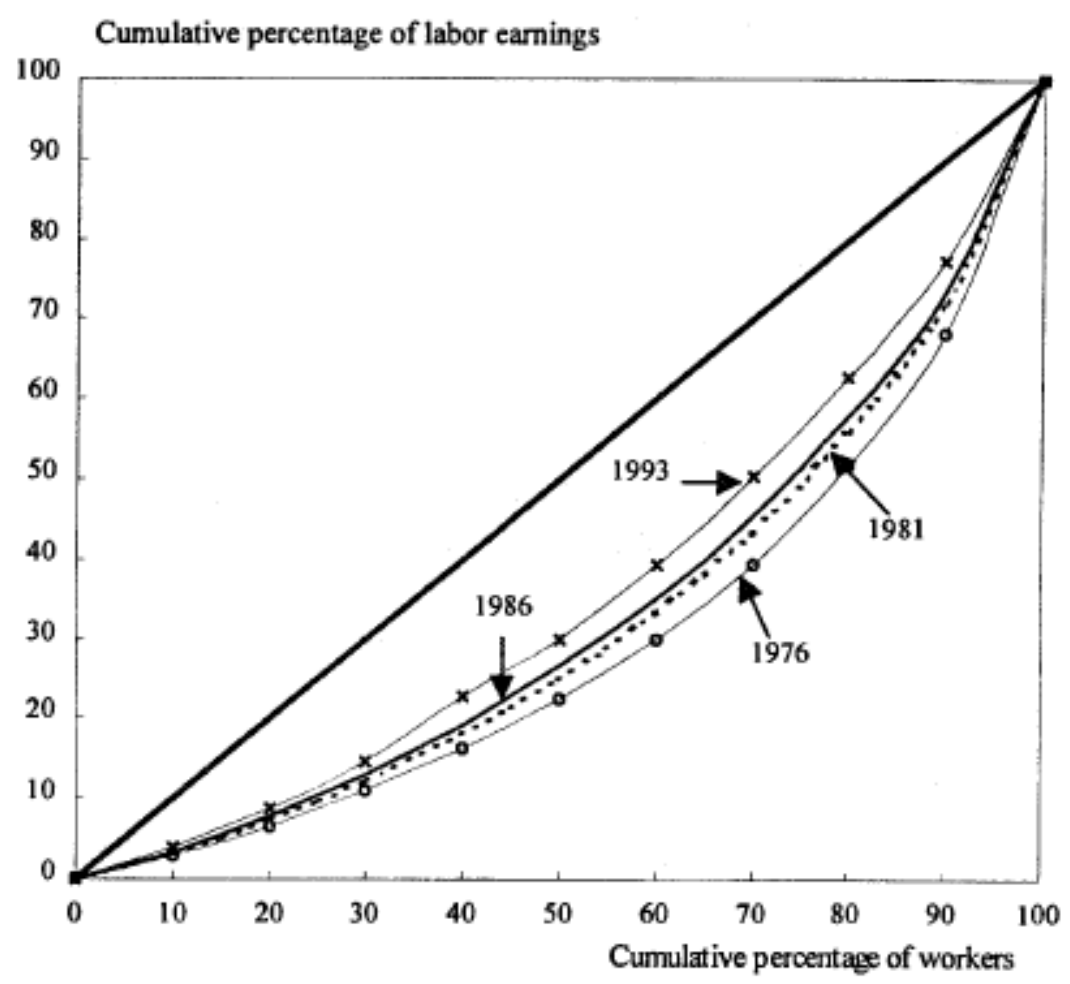

Figure 2. Lorenz Curves for Labor Incomes in Korea, 1976-93

TABLE 1

LORENZ COMPARISONS OF LABOUR INCOME INEQUALITY IN KOREA, 1976-93

\begin{tabular}{lccc}
\hline \hline & 1981 & 1986 & 1993 \\
\hline 1976 & LI & LI & LI \\
1981 & & LI & LI \\
1986 & & & LI \\
\hline
\end{tabular}

Note: LI: The change from the earlier year to the later year is a Lorenz-improvement.

LW: The change from the earlier year to the later year is a Lorenz-worsening.

LC: The two years' Lorenz curves cross. 
TABLE 2

A. Earnings Differentuals by Educational. Attainment

(High School $=100$ )

\begin{tabular}{|c|c|c|c|c|c|c|}
\hline & \multicolumn{2}{|c|}{$\begin{array}{l}\text { Middle School } \\
\text { and Less }\end{array}$} & High School & \multicolumn{3}{|c|}{$\begin{array}{l}\text { University } \\
\text { and Over }\end{array}$} \\
\hline & 1976 & 59.1 & 100.0 & 145.3 & 229.7 & \\
\hline & 1981 & 69.0 & 100.0 & 143.3 & 225.0 & \\
\hline & 1986 & 77.6 & 100.0 & 129.0 & 222.0 & \\
\hline & 1993 & 88.1 & 100.0 & 109.5 & 161.3 & \\
\hline \multicolumn{7}{|c|}{$\begin{array}{l}\text { B. EARNINGS DifFERENTLALS BY OCCUPATION } \\
\text { (Average Earnings in a Given Year }=100 \text { ) }\end{array}$} \\
\hline Year & $\begin{array}{c}\text { Professional } \\
\text { and } \\
\text { Technical }\end{array}$ & $\begin{array}{c}\text { Administrative } \\
\text { and } \\
\text { Managerial }\end{array}$ & $\begin{array}{l}\text { Clerical } \\
\text { and } \\
\text { Related }\end{array}$ & Sales & Services & Production \\
\hline 1971 & 179.9 & 270.9 & 151.6 & 90.2 & 69.2 & 78.1 \\
\hline 1976 & 211.5 & 343.6 & 161.2 & 81.4 & 74.4 & 72.5 \\
\hline 1982 & 182.4 & 259.6 & 119.0 & 100.5 & 76.9 & 75.2 \\
\hline 1986 & 172.6 & 241.1 & 113.6 & 98.4 & 73.0 & 75.8 \\
\hline 1992 & 127.2 & 211.3 & 102.2 & 78.3 & 69.3 & 83.9 \\
\hline \multicolumn{7}{|c|}{ C. EARnings DiffERentials by GENDER } \\
\hline \multicolumn{7}{|c|}{$\begin{array}{l}\text { Ratio of Female to Male Eamings } \\
\text { (\%) }\end{array}$} \\
\hline & 1980 & & 42.9 & & & \\
\hline & 1986 & & 48.0 & & & \\
\hline & 1993 & & 54.6 & & & \\
\hline \multicolumn{7}{|c|}{ D. Earnings Differentials by Size of Firm } \\
\hline Year & $10-29$ & $30-99$ & $00-299$ & $300-499$ & or More & \\
\hline 1980 & 92.9 & 99.1 & 97.1 & 102.3 & 100 & \\
\hline 1986 & 82.9 & 92.4 & 91.7 & 99.5 & 100 & \\
\hline 1993 & 73.7 & 77.1 & 85.6 & 91.5 & 100 & \\
\hline \multicolumn{7}{|c|}{ E. UNION-NONUNION EARNINGS DIFFERENTIALS } \\
\hline \multicolumn{7}{|c|}{$\begin{array}{c}\text { Gross Earnings Differential } \\
\qquad \%\end{array}$} \\
\hline & 1986 & & 8.6 & & & \\
\hline & 1993 & & 26.9 & & & \\
\hline
\end{tabular}

The methodology presented below addresses both of these limitations. On the first, our point of departure is the earnings function coefficients obtained from multiple regressions, which gauge the effect of one explanatory variable controlling for the effects of others. As for the second, the method we use enables us to quantify the relative importance of each factor.

\section{The Methodology used to Account for Income Inequality and Its Change}

\section{A. Introduction}

For decades, economists have sought to understand the inequality of income (or earnings or wages) using regression models. ${ }^{7}$ Typically, the logarithm of the income of individual $i$ in country/group/time $t$ is regressed on a number of explanatory variables. Assuming that these have been chosen carefully in light of theory and past empirical findings, the question then is how to use the information contained in such income-generating equations to "account for" or "decompose" income inequality. 
Fields (1998) has proposed a new decomposition methodology, the results of which are highlighted here. Two questions are posed. First, given an income generating function estimated by a standard semi-logarithmic regression, how much income inequality is accounted for by each explanatory factor (and how much is unexplained, as gauged by the residual) ${ }^{8}$ This shall be termed the "levels question," the answer to which is of the form "x percent of the inequality of income is attributable to education, y percent to region, etc. and z percent is unexplained." Second, how much of the difference in income inequality between one country and another, between one group and another within a country, or between one date and another is accounted for by education, by potential experience, and by the other explanatory factors? This shall be called the "differences question."

\section{B. The "Levels" Question}

To account for income inequality at a point in time, start with an income generating function, based on human capital theory or some other underlying theoretical model:

$$
\ln \left(Y_{i 1}\right)=\alpha_{1}+\sum_{k} B_{k 1} X_{i k 1}+\epsilon_{1}
$$

and

$$
\ln \left(Y_{i 2}\right)=\alpha_{1}+\sum_{k} B_{k 2} X_{i k 2}+\epsilon_{2}
$$

where the subscripts 1 and 2 denote two countries, groups, or dates. Rewrite the incomegenerating functions as

$$
\ln \left(Y_{i t}\right)=\sum_{j} \alpha_{j t} Z_{i j t}=\alpha^{\prime} Z
$$

and

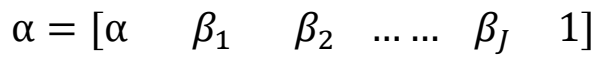

and

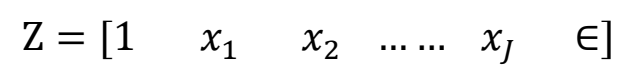

We have, for the "levels" question:

Result 1. Given the income-generating function (3a-c), let an inequality index $I(\ln \mathrm{Y})$ be defined on the vector of $\log$-incomes In $Y=\left(\ln \mathrm{Y}_{1}, \ldots, \ln \mathrm{Y}_{\mathrm{N}}\right)$. Under six axioms proposed by Shorrocks (1982), the decomposition of income inequality given by 


$$
s_{j}(\ln Y)=\frac{\operatorname{cov}\left[a_{j} Z_{j}, \ln Y\right]}{\sigma^{2}(\ln Y)}=\frac{a_{j} * \sigma\left(Z_{j}\right) * \operatorname{cor}\left[Z_{j}, \ln Y\right]}{\sigma(\ln Y)}
$$

where

$$
\begin{aligned}
& \sum_{j} s_{j}(\ln Y)=100 \% \\
& \sum_{J=1}^{J+1} \frac{\operatorname{cov}\left[a_{j} Z_{j}, \ln Y\right]}{\sigma^{2}(\ln Y)}=R^{2}(\ln Y),
\end{aligned}
$$

and

$$
p_{j}(\ln Y)=\frac{s_{j}(\ln Y)}{R^{2}(\ln Y)}
$$

holds for any inequality index $I\left(\ln \mathrm{Y}_{1}, \ldots, \ln \mathrm{Y}_{\mathrm{N}}\right)$ which is continuous and symmetric and for which $I(\mu, \mu, \ldots, \mu)=0$.

These conditions hold for a broad class of inequality measures including all of the standard ones such as the Gini coefficient, the Atkinson index, the generalized entropy family, and various centile measures.

Result 1 is quite powerful. It says that in the levels context, as long as we agree on the log-linear model (3) and on the decomposition rules, we do not need to agree on which particular inequality measure to decompose, because we get the same percentage effect for the $j$ - th explanatory factor for all of the standard measures applied to the logarithms of income.

\section{The Differences Question}

How would we account for differences in income inequality between one time and another? ${ }^{10}$ More specifically: How much of the change in inequality from one time to another is attributable to each income determinant? Which is relatively more important in accounting for these changes: differences in education, in tenure and experience, in unionization, etc? How may the contributions of each of these factors be broken down in turn into a coefficients effect, an inequality effect, and a correlation effect?

Result 1 established that the $\mathrm{j}$ - th factor's percentage contribution to the level of inequality is the same for a broad class of inequality measures. This leads one to ask, are the percentage contributions to the changes in inequality similarly independent of how inequality is measured? The answer is readily seen to be "no": the amount by which inequality rose or felland perhaps even whether inequality rose or fell-depends on how inequality is measured.

Suppose a particular inequality measure $I(\bullet)$ is chosen for decomposition. (The ones used below are the Gini coefficient and the log-variance.) The contribution of the $\mathrm{j}$ - th explanatory factor to the change in inequality as measured by $I(\bullet)$ can be obtained by noting that 


$$
I(\cdot)_{2}-I(\cdot)_{1}=\sum_{j}\left[s_{j, 2} * I(\cdot)_{2}-s_{j, 1} * I(\cdot)_{1}\right],
$$

defining the contribution of factor $y$ to the change in inequality for an arbitrary inequality measure $I(\bullet)$ as

$$
\pi_{j}(I(\cdot))=\frac{\left[s_{j, 2} * I(\cdot)_{2}-s_{j, 1} * I(\cdot)_{1}\right]}{\left[I(\cdot)_{2}-I(\cdot)_{1}\right]}
$$

and then observing that

$$
100 \%=\frac{\sum j\left[s_{j, 2} * I_{2}-s_{j, 1} * I_{1}\right]}{I_{2}-I_{1}}=\sum_{j} \pi_{j}(I(\cdot)) .
$$

Thus:

Result 2. The contribution of the $\mathrm{j}$ - th factor to the change in a particular inequality measure between country/group/time 1 and country/group/time 2 is given by

$$
\pi_{j}(I(\cdot))=\frac{\left[s_{j, 2} * I(\cdot)_{2}-s_{j, 1} * I(\cdot)_{1}\right]}{\left[I(\cdot)_{2}-I(\cdot)_{1}\right]},
$$

Writing $\pi_{j}$, as a function of $I(\bullet)$ makes explicit that the explanatory contribution of the $\mathrm{j}$ th factor depends on the inequality measure used. It is an empirical question whether the choice of inequality measure makes a large difference or a small one in any particular context. For Korea, the differences are found to be small.

Finally, let us consider how to account for the sources of changing contributions of the various factors explaining income inequality. If the same income generating functions have been run for two samples at different dates and the $s_{j}-s$ given by (4a) are found to differ, one may ask, "why"? To what extent is the change in any given $\mathrm{s}_{\mathrm{j}}$ due to differences between the regression coefficients in the two years; to differences in the inequality of the explanatory variable; to differences in the covariance or the correlation between the explanatory variable and income?

For infinitesimal changes, an exact decomposition of the difference in any given $\mathrm{s}_{\mathrm{j}}$ can be obtained by logarithmically differentiating (4a) to obtain

$$
\widehat{s_{j}(\overline{\ln Y})}=\widehat{a}_{j}+\widehat{\sigma\left(Z_{j}\right)}+\widehat{\operatorname{cor}\left(Z_{j}, \ln Y\right)}-\widehat{\sigma(\ln Y)},
$$

the ${ }^{\wedge}$ over the variable indicating a percentage rate of growth. In real-world applications, the changes in each component are non-infinitesimal. Dividing through by pctchng $\left(\mathrm{s}_{\mathrm{j}},(\ln \mathrm{Y})\right)$, the change in $\mathrm{s}_{\mathrm{j}}$ may then be approximated by

$$
1 \approx \frac{p \operatorname{ctchng}\left(a_{j}\right)}{\left.p \operatorname{ctchng}\left(s_{j}(\ln Y)\right)\right)}+\frac{p \operatorname{ctchng}\left[\sigma\left(Z_{j}\right)\right]}{p \operatorname{ctchng}\left(s_{j}(\ln Y)\right)}+\frac{p \operatorname{ctchng}\left[\operatorname{cor}\left[Z_{j}, \ln Y\right]\right]}{p \operatorname{ctchng}\left(s_{j}(\ln Y)\right)}-\frac{p \operatorname{ctchng}[\sigma(\ln Y)]}{p \operatorname{ctchng}\left(s_{j}(\ln Y)\right)}
$$


An objection to (9) is that $\mathrm{a}_{\mathrm{j}}$ and cor $\left[\mathrm{Z}_{\mathrm{j}}\right.$, In $\left.\mathrm{Y}\right]$ are both functions of cov $\left[\mathrm{Z}_{\mathrm{j}}\right.$, In $\left.\mathrm{Y}\right]$, so that one cannot be varied without the other. ${ }^{11}$ This objection can be overcome by making a further approximation. If the $\mathrm{j}$ - th income-determining factor were orthogonal to the other incomedetermining factors, that determinant's factor inequality weight would equal

$$
s_{j}(\ln Y)=\frac{a^{2} j * \sigma^{2}\left(Z_{j}\right)}{\sigma^{2}(\ln Y)}
$$

The changes over time would then decompose approximately as

$$
1 \approx \frac{2 * \operatorname{pctchng}\left(a_{j}\right)}{p \operatorname{ctchng}\left(s_{j}\right)}+\frac{2 * \operatorname{pctchng}\left[\sigma\left(Z_{j}\right)\right.}{\operatorname{pctchng}\left(s_{j}\right)}-\frac{2 * \operatorname{pctchng}[\sigma(\ln Y)]}{\operatorname{pctchng}\left(s_{j}\right)}
$$

("Approximately" for two reasons: (i) real-world changes are not infinitesimal, and (ii) the j - th regressor is typically not orthogonal to the other regressors.) On the other hand, the advantage of the decomposition in (11) over that in (9) is that it says that the $\mathrm{j}$ - th regressor in the incomegenerating function contributes more to accounting for an observed increase in inequality (a) the larger is the increase in the regression coefficient of that variable, and (b) the larger is the increase in the inequality of that variable as measured by the standard deviation - both intuitively appealing results. In the case of falling inequality, (11) says that the $\mathrm{j}$ - th regressor contributes more to the decrease in inequality (a) the larger is the decrease in the regression coefficient on that factor and (b) the larger is the decrease in the standard deviation of that factor.

Using these alternative decompositions, we then have:

Result 3. The change in the $\mathrm{j}$ - th explanatory factor's relative factor inequality weight can be approximated by

$$
1 \approx \frac{p \operatorname{ctchng}\left(a_{j}\right)}{\left.p \operatorname{ctchng}\left(s_{j}(\ln Y)\right)\right)}+\frac{p \operatorname{ctchng}\left[\sigma\left(Z_{j}\right)\right]}{p \operatorname{ctchng}\left(s_{j}(\ln Y)\right)}+\frac{p \operatorname{ctchng}\left[\operatorname{cor}\left[Z_{j}, \ln Y\right]\right]}{p \operatorname{ctchng}\left(s_{j}(\ln Y)\right)}-\frac{p \operatorname{ctchng}[\sigma(\ln Y)]}{p \operatorname{ctchng}\left(s_{j}(\ln Y)\right)}
$$

or as

$$
1 \approx \frac{2 * \operatorname{pctchng}\left(a_{j}\right)}{\operatorname{pctchng}\left(s_{j}\right)}+\frac{2 * \operatorname{pctchng}\left[\sigma\left(Z_{j}\right)\right]}{\operatorname{pctchng}\left(s_{j}\right)}-\frac{2 * \operatorname{pctchng}[\sigma(\ln Y)]}{\operatorname{pctchng}\left(s_{j}\right)}
$$

In practice, both approximations prove to be quite close; see Section 4.

\section{Decomposition Results for Korea}

\section{A. Inequality in Korea, 1993}

Many factors have been cited to explain labor income inequality in Korea. In order to quantify their relative importance, we follow the procedure described in Section 3 by first setting up a regression model in which the logarithm of labor income of worker $i$ at time $t$ is regressed on a number of characteristics of that worker: 


$$
\ln \left(Y_{i t}\right)=\sum_{j} \alpha_{j t} z_{i j t}=\alpha^{\prime} Z
$$

where

$$
\alpha=\left[\begin{array}{llllll}
\alpha & \beta_{1} & \beta_{2} & \ldots \ldots & \beta_{J} & 1
\end{array}\right]
$$

and

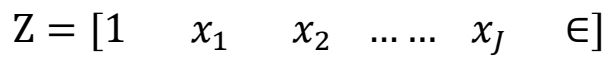

Our base model, which we shall refer to as the "full specification in log-income," includes the variables listed in Table 3.

The results for all workers taken together in 1993 are shown in column (1) of Table 4. The first thing to note is that with one exception, all variables are 
TABLE 3

VARIABLES USED IN THE RFGRESSIONS

\begin{tabular}{|c|c|}
\hline Variable & Definition \\
\hline $\begin{array}{l}\text { Dependent } \\
\text { Logearn }\end{array}$ & logarithm of monthly labor income, including overtime and bonuses \\
\hline \multicolumn{2}{|c|}{ Expanatory variables: } \\
\hline Yedu & \\
\hline $\begin{array}{l}\text { Female } \\
\text { Union }\end{array}$ & $\begin{array}{l}\text { indicator variable, } 1 \text { if female } \\
\text { indicator variable. I if workplace is covered by a union }\end{array}$ \\
\hline $\begin{array}{l}\text { Unonon } \\
\text { Married }\end{array}$ & indicator variable, 1 if married \\
\hline Tenure & years of tenure in current job \\
\hline Tensqr & years of tenure in current job, squared \\
\hline Potexp & years of potential experience, calculated as age-yedu- 6 \\
\hline Potexpsq & years of potential experience, squared \\
\hline \multicolumn{2}{|c|}{ Size of establishment indicator variables: } \\
\hline & $10-29$ \\
\hline Siz2 & $30-99$ \\
\hline Siz3 & $\begin{array}{l}100-299 \\
300-409\end{array}$ \\
\hline $\begin{array}{l}\text { Siz4 } \\
\text { Sizs }\end{array}$ & $\begin{array}{l}300-499 \\
500 \text { or more }\end{array}$ \\
\hline \multicolumn{2}{|c|}{ Regian indicator variables: } \\
\hline Regl & Seoul \\
\hline Reg2 & Pusan \\
\hline $\operatorname{Reg} 3$ & Inchun and Gyunggi \\
\hline $\operatorname{Reg} 4$ & Gangwon \\
\hline $\begin{array}{l}\text { Reg5 } \\
\text { Reg6 }\end{array}$ & Chungchong \\
\hline $\begin{array}{l}\text { Reg6 } \\
\text { Reg? }\end{array}$ & $\begin{array}{l}\text { Jeju and Junra } \\
\text { Daegu and Gyungsang }\end{array}$ \\
\hline \multirow{2}{*}{\multicolumn{2}{|c|}{$\begin{array}{l}\text { Occupational indicator variables, } 1986 \text { and beforc: } \\
\text { Occl }\end{array}$}} \\
\hline Ocel & \\
\hline Occ2 & administrative and managerial \\
\hline Occ3 & clerical \\
\hline Occ4 & sales and services \\
\hline Oces & production \\
\hline \multicolumn{2}{|c|}{ Occupational indicator variables, 1993 : } \\
\hline Occl & $\begin{array}{l}\text { legislators, senior officials and managers } \\
\text { professionals }\end{array}$ \\
\hline $\begin{array}{l}\text { Occ2 } \\
\text { Oce3 } 3\end{array}$ & $\begin{array}{l}\text { professionals } \\
\text { technical and kindred }\end{array}$ \\
\hline Occ4 & clerical \\
\hline Oec5 & service workers, shop and sales workers \\
\hline Occo & skilled agricultural and fishery workers \\
\hline Ox? & craft and related trades workers \\
\hline Occ8 & operators and assemblers \\
\hline Oxc9 & elementary occupations \\
\hline \multirow{2}{*}{\multicolumn{2}{|c|}{$\begin{array}{l}\text { Industry indicator variables, } 1986 \text { and before: } \\
\text { IndI not used }\end{array}$}} \\
\hline & $\begin{array}{l}\text { not used } \\
\text { agriculture, forestry, fishing, mining and quarrying }\end{array}$ \\
\hline $\begin{array}{l}\text { Ind2 } \\
\text { Ind3 }\end{array}$ & \\
\hline Ind4 & heavy manufacturing \\
\hline Ind5 & electricity, gas, water, transport, storage, communication \\
\hline Ind6 & construction \\
\hline Ind7 & trade, restaurants, hotels, finance, insurance, real estate \\
\hline Ind8 & other services \\
\hline \multicolumn{2}{|c|}{ Industry indicator variables, 1993 : } \\
\hline $\begin{array}{l}\text { Ind I } \\
\text { Ind2 }\end{array}$ & mining and quarrying \\
\hline $\begin{array}{l}\text { Ind2 } \\
\text { Ind3 }\end{array}$ & $\begin{array}{l}\text { manufacturing } \\
\text { electricity, gas, steam and water supply }\end{array}$ \\
\hline Ind4 & $\begin{array}{l}\text { electricity, gas, steam and water supply } \\
\text { construction }\end{array}$ \\
\hline Inds & wholesale and retail trade, repair, hotel and restaurants \\
\hline Ind6 & transport, storage and communications \\
\hline Ind7 & financial intermediate, real estate, rental and business activities \\
\hline Ind8 & $\begin{array}{l}\text { educational, health and social work, other community, social and personal service } \\
\text { activities }\end{array}$ \\
\hline
\end{tabular}


highly statistically significant at the 0.01 level or better. ${ }^{12}$ We find that holding other things equal: ${ }^{13}$

- Education raises income, but by a surprisingly small amount: just 3.6 percent per year.

- Being married raises income by an estimated 6.2 percent, holding other things equal including hours of work.

- Being a union member raises income, by an estimated 5.8 percent.

- Being a woman lowers income by 31.4 percent.

- An increase in working hours raises monthly labor income, with an elasticity of 0.33 .

- Labor income increases with potential experience for the first 25 years of experience and decreases thereafter, producing an inverted-U-shaped pattern.

- Labor income increases with tenure on the job for the first 23 years of tenure and decreases thereafter, producing an inverted-U-shaped pattern.

- The larger the firm, the higher is labor income. The largest firms pay an estimated 12 percent more than do the smallest firms covered by the OWS.

- Labor incomes in the various regions of Korea are two to ten percent lower than they are in Seoul, other things equal, with the exception of the Daegu-Gyungsang region, which is not significantly different from Seoul.

- Labor incomes rise as one moves up the occupational scale.

- Other things equal, the highest-paying industries are mining, finance, education, and construction, while the lowest-paying ones are manufacturing, public utilities, and transport.

Based on these regression results, we used the decomposition equation (8) to quantify the importance of these various factors in accounting for the level of labor income inequality in Korea in 1993. Column (4) of Table 5 reports the results. What stands out in these results is that despite the high level of statistical significance of all of these variables in the earnings regression in Table 4, they account for widely divergent shares of Korea's labor income inequality. Live variables explain fairly sizeable shares of inequality - job tenure, female, occupation, years of education, and potential experience - while virtually nothing is explained by the remaining factors (marital status, firm size, union, industry, region, and hours worked).

\section{B. Changing Inequality in Korea, 1986-93}

Between 1986 and 1993, the Korean economy grew at an average annual rate of 8.0 percent and experienced a Lorenz-improvement, producing a five percentage point reduction in the Gini coefficient of labor earnings, from 0.34 to 0.29 . This was a particularly important time in Korea's history, because of the major political liberalization that took place in June 1987. The 1987 events were significant for the labor market, because the government suddenly relaxed its long-standing suppression of trade union activities. Consequently, a rash of strikes broke out and lasted through 1989. At that point, the industrial relations climate stabilized in a way that is widely thought to have resulted in stronger labor unions than before. 14

It might be expected that stronger labor unions would have contributed to a reduction in the inequality of labor incomes by raising the wages of workers at the bottom end of the wage 
scale and/or by equalizing the wages of union members ("equal pay for equal work"). The methodology described in Results 2 and 3 of Section 3 may be used to test this hypothesis and to gauge the relative equalizing effect of unions compared with other labor market factors such as the narrowing of the educational and gender earnings differentials.

First, the logarithm of labor earnings was regressed on the explanatory variables listed in Table 3, for 1986 as well as 1993.15 The 1993 regression results have already been discussed. The regression results appear in column (4) of Table 4.

The 1986 results are very similar to the 1993 results. In both years, additional education, being married, being a union member, working more hours, and working for a larger firm raised income, while being female and residing outside of Seoul lowered income. The effects of potential experience and job tenure were inverted-U-shaped. Occupation and industry effects were statistically significant and noteworthy.

Table 5 presents the decomposition results for 1986 in column (1) and those for 1993 in column (4). We see that the same five factors that were important in accounting for labor income inequality in 1993 - job tenure, female, occupation, education, and potential experience - were also the important ones in 1986, albeit with some rank reversals. This strengthens the conclusion about what was important and what was not important in determining the level of income inequality in Korea.

Next, we examined to what extent the factors that contributed importantly to the level of income inequality are also important in determining the change in inequality using the method shown in Result 3. The factor that is found to make the largest positive contribution to explaining the falling labor income inequality in Korea is years of education. As shown in column (11) of Table 5, education accounted for 33 percent of the fall in the log-variance - about twice what is accounted for by the next most important variables.

Table 6 decomposes the effects of education further, using equations (8) and (10) to break down the change in education's contribution into subcomponents corresponding to the change in the coefficient on education in the earnings equation, the change in the standard deviation of years of education, and the change in the correlation between years of education and earnings. We see that the most important factor was the reduction over time in the coefficient on an extra year of education (from 0.055 to 0.036 ) in the earnings function. Next most important (decomposition according to (8) only) was the fact that education came to be less correlated with earnings than it had been. Changing inequality in the distribution of years of education was not a factor, because years of education came to be less equally distributed than before.

Another variable merits particular attention because of its unimportance. In view of the attention paid to unions in Korea, the small explanatory power manifested by the union variable is striking. One reason for union's unimportance is that the union wage effect was growingfrom 3.0 percent in 1986 to 5.8 percent in 1993 - which works in the direction of increasing inequality at a time when inequality was decreasing. Another reason for union's unimportance is that these union relative wage effects are modest compared to the gender differentials $(30.7$ percent and 31.4 percent respectively in the same two years).16 These findings suggest that the 
change in the industrial relations climate in 1987 was not responsible for the fall in labor income inequality in Korea between 1986 and 1993. 
TABLE 4

DETERMINANTS OF EARNINGS: 1993, 1986

(Regression coefficients, absolute value of $t$-statistics in parentheses)

\begin{tabular}{|c|c|c|c|c|c|c|}
\hline \multirow[b]{2}{*}{ Variable } & \multicolumn{3}{|c|}{1993} & \multicolumn{3}{|c|}{1986} \\
\hline & (1) All & $\begin{array}{c}1993 \\
(2) \mathrm{Men}\end{array}$ & (3) Women & (4) All & $\begin{array}{c}1986 \\
\text { (5) Men }\end{array}$ & (6) Women \\
\hline Constant & $\begin{array}{c}11.597^{* *} \\
(216.81)\end{array}$ & $\begin{array}{c}11.790^{* *} \\
(195.22)\end{array}$ & $\begin{array}{l}10.661^{* *} \\
(81.18)\end{array}$ & $\begin{array}{l}10.570 * * \\
(224.57)\end{array}$ & $\begin{array}{l}10.873 * * \\
(179.28)\end{array}$ & $\begin{array}{l}9.690 * * \\
(130.94)\end{array}$ \\
\hline Yedu & $\begin{array}{l}0.036^{* *} \\
(47.48)\end{array}$ & $\begin{array}{l}0.037^{* *} \\
(43.18)\end{array}$ & $\begin{array}{l}0.040^{* * *} \\
(24.93)\end{array}$ & $\begin{array}{c}0.055^{* *} \\
(77.39)\end{array}$ & $\begin{array}{c}0.059^{* *} \\
(67.26)\end{array}$ & $\begin{array}{l}0.040^{* *} \\
(34.72)\end{array}$ \\
\hline Married & $\begin{array}{c}0.062^{* *} \\
(13.37)\end{array}$ & $\begin{array}{c}0.092^{* *} \\
(17.50)\end{array}$ & $\begin{array}{l}0.021 * * \\
(2.27)\end{array}$ & $\begin{array}{l}0.075 * * \\
(16,87)\end{array}$ & $\begin{array}{c}0.106 * * \\
(19.14)\end{array}$ & $\begin{array}{r}-0.001 \\
(0.14)\end{array}$ \\
\hline Union & $\begin{array}{l}0.058^{* *} \\
(16.36)\end{array}$ & $\begin{array}{l}0.046^{* *} \\
(10.83)\end{array}$ & $\begin{array}{c}0.080^{* *} \\
(12.86)\end{array}$ & $\begin{array}{l}0.030^{* *} \\
(8.53)\end{array}$ & $\begin{array}{l}0.022 * * \\
(4.82)\end{array}$ & $\begin{array}{l}0.041^{* *} \\
(8.51)\end{array}$ \\
\hline Female & $\begin{array}{l}-0.314^{* *} \\
(86.10)\end{array}$ & & & $\begin{array}{l}-0.307^{* *} \\
(88.88)\end{array}$ & & \\
\hline Loghour & $\begin{array}{l}0.327^{* *} \\
(35.33)\end{array}$ & $\begin{array}{l}0.269^{* *} \\
(25.38)\end{array}$ & $\begin{array}{l}0.511^{* *} \\
(28.27)\end{array}$ & $\begin{array}{c}0.237^{* *} \\
(27.54)\end{array}$ & $\begin{array}{l}0.141^{* *} \\
(12.55)\end{array}$ & $\begin{array}{l}0.411^{*} \\
(33.60)\end{array}$ \\
\hline Potexp & $\begin{array}{l}0.021^{* *} \\
(35.99)\end{array}$ & $\begin{array}{l}0.028^{* *} \\
(38.00)\end{array}$ & $\begin{array}{l}0.015^{* *} \\
(14.86)\end{array}$ & $\begin{array}{c}0.032^{* *} \\
(53.45)\end{array}$ & $\begin{array}{l}0.039 * * \\
(48.50)\end{array}$ & $\begin{array}{l}0.023 * * \\
(26.90)\end{array}$ \\
\hline Potexpsq & $\begin{array}{l}-0.000^{* *} \\
(34.10)\end{array}$ & $\begin{array}{l}-0.001^{* *} \\
(34.73)\end{array}$ & $\begin{array}{l}-0.000^{* *} \\
(14.95)\end{array}$ & $\begin{array}{l}-0.001^{* *} \\
(48.98)\end{array}$ & $\begin{array}{l}-0.001^{* *} \\
(42.46)\end{array}$ & $\begin{array}{l}-0.001^{* *} \\
(28.47)\end{array}$ \\
\hline Tenure & $\begin{array}{c}0.058^{* *} \\
(74,83)\end{array}$ & $\begin{array}{l}0.050^{* *} \\
(56.61)\end{array}$ & $\begin{array}{c}0.074^{* *} \\
(43.78)\end{array}$ & $\begin{array}{c}0.055^{* *} \\
(68.77)\end{array}$ & $\begin{array}{c}0,047^{* *} \\
(47,16)\end{array}$ & $\begin{array}{l}0.065^{* *} \\
(44.30)\end{array}$ \\
\hline Tensqr & $\begin{array}{l}-0.001^{* *} \\
(37.33)\end{array}$ & $\begin{array}{l}-0.001^{* * *} \\
(27.90)\end{array}$ & $\begin{array}{l}-0.002^{* *} \\
(16.70)\end{array}$ & $\begin{array}{l}-0.001^{* *} \\
(28.69)\end{array}$ & $\begin{array}{l}-0.001^{* *} \\
(19.73)\end{array}$ & $\begin{array}{c}-0.001^{* *} \\
(8.84)\end{array}$ \\
\hline Sizz & $\begin{array}{l}0.020^{* *} \\
(4.69)\end{array}$ & $\begin{array}{l}0.034^{* * *} \\
(6.71)\end{array}$ & $\begin{array}{r}0.009 \\
(1.23)\end{array}$ & $\begin{array}{c}0.062^{* *} \\
(14.19)\end{array}$ & $\begin{array}{l}0.056^{* *} \\
(10.12)\end{array}$ & $\begin{array}{l}0.084^{* *} \\
(12.67)\end{array}$ \\
\hline Siz3 & $\begin{array}{l}0.055^{* *} \\
(11.28)\end{array}$ & $\begin{array}{c}0.079 * * \\
(13.38)\end{array}$ & $\begin{array}{l}0.018^{*} \\
(2.11)\end{array}$ & $\begin{array}{c}0.133^{* *} \\
(28,52)\end{array}$ & $\begin{array}{c}0.159 * * \\
(26.38)\end{array}$ & $\begin{array}{l}0.073^{* *} \\
(10.51)\end{array}$ \\
\hline Siz 4 & $\begin{array}{l}0.068^{* * *} \\
(10.12)\end{array}$ & $\begin{array}{l}0.088^{* *} \\
(11.04)\end{array}$ & $\begin{array}{l}0.034^{* *} \\
(2.87)\end{array}$ & $\begin{array}{l}0.153^{* *} \\
(25.93)\end{array}$ & $\begin{array}{l}0.168 * * \\
(21.72)\end{array}$ & $\begin{array}{l}0.119^{* *} \\
(13.95)\end{array}$ \\
\hline Sizs & $\begin{array}{c}0.121^{*} \\
(23.18)\end{array}$ & $\begin{array}{l}0.145^{* *} \\
(23.73)\end{array}$ & $\begin{array}{l}0.075^{* *} \\
(7.95)\end{array}$ & $\begin{array}{l}0.207^{* *} \\
(42.50)\end{array}$ & $\begin{array}{c}0.232^{* * *} \\
(36.82)\end{array}$ & $\begin{array}{l}0.150^{* *} \\
(20.66)\end{array}$ \\
\hline $\operatorname{Reg} 2$ & $\begin{array}{l}-0.068^{* *} \\
(11.17)\end{array}$ & $\begin{array}{l}-0.055^{* *} \\
(7.52)\end{array}$ & $\begin{array}{l}-0.090^{* * *} \\
(8.70)\end{array}$ & $\begin{array}{l}-0.112^{* *} \\
(24.40)\end{array}$ & $\begin{array}{l}-0.106^{* *} \\
(16.46)\end{array}$ & $\begin{array}{l}-0.101 * * \\
(17.09)\end{array}$ \\
\hline $\operatorname{Reg} 3$ & $\begin{array}{l}-0.017 * * \\
(3.76)\end{array}$ & $\begin{array}{l}-0.0222^{* *} \\
(4.02)\end{array}$ & $\begin{array}{r}-0.009 \\
(1.08)\end{array}$ & $\begin{array}{l}-0.050^{* *} \\
(12.70)\end{array}$ & $\begin{array}{l}-0.053^{* *} \\
(10.17)\end{array}$ & $\begin{array}{l}-0.041^{* .} \\
(7.57)\end{array}$ \\
\hline Reg4 & $\begin{array}{l}-0.074^{* *} \\
(11.34)\end{array}$ & $\begin{array}{l}-0.061^{* *} \\
(7.90)\end{array}$ & $\begin{array}{l}-0.100^{* *} \\
(8.73)\end{array}$ & $\begin{array}{l}-0.061^{* *} \\
(6,52)\end{array}$ & $\begin{array}{l}-0.039 * * \\
(3.53)\end{array}$ & $\begin{array}{l}-0.161^{* .} \\
(8.85)\end{array}$ \\
\hline $\operatorname{Reg} 5$ & $\begin{array}{l}-0.060^{* *} \\
(10.57)\end{array}$ & $\begin{array}{c}-0.051^{* * *} \\
(7.49)\end{array}$ & $\begin{array}{c}-0.081^{* *} \\
(8.16)\end{array}$ & $\begin{array}{l}-0.081^{* *} \\
(13.94)\end{array}$ & $\begin{array}{l}-0.089 * * \\
(11.69)\end{array}$ & $\begin{array}{c}-0.067^{*} \\
(8.16)\end{array}$ \\
\hline Reg6 & $\begin{array}{l}-0.100^{* *} \\
(18.74)\end{array}$ & $\begin{array}{l}-0.092^{* * *} \\
(14.69)\end{array}$ & $\begin{array}{l}-0.111^{* *} \\
(11.84)\end{array}$ & $\begin{array}{l}-0.144^{* *} \\
(26.38)\end{array}$ & $\begin{array}{l}-0.147^{* * *} \\
(20.91)\end{array}$ & $\begin{array}{l}-0.142^{* *} \\
(17.70)\end{array}$ \\
\hline $\operatorname{Reg} 7$ & $\begin{array}{r}0.000 \\
(0.03)\end{array}$ & $\begin{array}{c}-0.004 \\
(0.71)\end{array}$ & $\begin{array}{r}-0.000 \\
(0.05)\end{array}$ & $\begin{array}{l}-0.076^{* *} \\
(20.03)\end{array}$ & $\begin{array}{l}-0.079 * * \\
(15.73)\end{array}$ & $\begin{array}{l}-0.071^{* *} \\
(13.40)\end{array}$ \\
\hline Occ2 & $\begin{array}{l}-0.212^{* * *} \\
(23.68)\end{array}$ & $\begin{array}{l}-0.196^{* *} \\
(20.82)\end{array}$ & $\begin{array}{l}-0.653^{* *} \\
(13.90)\end{array}$ & $\begin{array}{l}0.151^{* *} \\
(17.77)\end{array}$ & $\begin{array}{l}0.156^{* *} \\
(16.39)\end{array}$ & $\begin{array}{l}0.169^{* *} \\
(3.31)\end{array}$ \\
\hline Oec 3 & $\begin{array}{l}-0.268^{* *} \\
(30.32)\end{array}$ & $\begin{array}{l}-0.242^{* *} \\
(26.50)\end{array}$ & $\begin{array}{l}-0.733^{* *} \\
(15.35)\end{array}$ & $\begin{array}{l}-0.174^{* *} \\
(30.50)\end{array}$ & $\begin{array}{l}-0.133^{* *} \\
(19.32)\end{array}$ & $\begin{array}{l}-0.402 * \\
(35.18)\end{array}$ \\
\hline Occ4 & $\begin{array}{l}-0.310^{* *} \\
(39.18)\end{array}$ & $\begin{array}{l}-0.301^{*} \\
(36.72)\end{array}$ & $\begin{array}{l}-0.815^{* *} \\
(17.65)\end{array}$ & $\begin{array}{l}-0.514^{* *} \\
(62.92)\end{array}$ & $\begin{array}{l}-0.489 * * \\
(47.80)\end{array}$ & $\begin{array}{l}-0.640^{* *} \\
(45,64)\end{array}$ \\
\hline
\end{tabular}


TABLE 4-continued

\begin{tabular}{|c|c|c|c|c|c|c|}
\hline \multirow[b]{2}{*}{ Variable } & \multicolumn{3}{|c|}{1993} & \multicolumn{3}{|c|}{1986} \\
\hline & (1) All & $\begin{array}{c}1993 \\
\text { (2) Men }\end{array}$ & (3) Women & (4) All & $\begin{array}{c}1986 \\
\text { (5) Men }\end{array}$ & (6) Women \\
\hline Occ5 & $\begin{array}{l}-0,407^{* *} \\
(38.32)\end{array}$ & $\begin{array}{l}-0,408^{* *} \\
(29.98)\end{array}$ & $\begin{array}{l}-0.884^{* *} \\
(18.93)\end{array}$ & $\begin{array}{l}-0.295 * * \\
(46.88)\end{array}$ & $\begin{array}{l}-0.241^{* *} \\
(32.29)\end{array}$ & $\begin{array}{l}-0.555 * * \\
(42.90)\end{array}$ \\
\hline Oco6 & $\begin{array}{l}-0.491^{* *} \\
(13.83)\end{array}$ & $\begin{array}{l}-0.495 * * \\
(11.56)\end{array}$ & $\begin{array}{l}-0.842^{* *} \\
(11.42)\end{array}$ & & & \\
\hline Oct 7 & $\begin{array}{l}-0.396^{* *} \\
(46.79)\end{array}$ & $\begin{array}{l}-0.342^{* *} \\
(38.18)\end{array}$ & $\begin{array}{l}-0.961^{* *} \\
(20.65)\end{array}$ & & & \\
\hline Oce8 & $\begin{array}{l}-0,372 * * \\
(44,57)\end{array}$ & $\begin{array}{l}-0.324 * \bullet \\
(36.90)\end{array}$ & $\begin{array}{l}-0.963 * * \\
(20.67)\end{array}$ & & & \\
\hline Occ 9 & $\begin{array}{l}-0 . .686^{* *} \\
(67.39)\end{array}$ & $\begin{array}{l}-0.670 * \\
(63.04)\end{array}$ & $\begin{array}{l}-1.069 * * \\
(22.52)\end{array}$ & & & \\
\hline Ind 2 & $\begin{array}{l}-0.191^{* *} \\
(10.67)\end{array}$ & $\begin{array}{c}-0.143^{* *} \\
(7.74)\end{array}$ & $\begin{array}{r}-0.064 \\
(0.89)\end{array}$ & & & \\
\hline Ind3 & $\begin{array}{c}-0.198^{* *} \\
(8.31)\end{array}$ & $\begin{array}{c}-0.135 * * \\
(5.45)\end{array}$ & $\begin{array}{l}-0.209+* \\
(2.40)\end{array}$ & $\begin{array}{l}-0,188^{* *} \\
(16.08)\end{array}$ & $\begin{array}{l}-0.163^{* *} \\
(1 \pm .92)\end{array}$ & $\begin{array}{c}-0.084^{* *} \\
(2.89)\end{array}$ \\
\hline Ind4 & $\begin{array}{l}-0.081^{* *} \\
(4.29)\end{array}$ & $\begin{array}{c}-0.044^{*} \\
(2.25)\end{array}$ & $\begin{array}{c}-0.042 \\
(0.56)\end{array}$ & $\begin{array}{l}-0.152^{* *} \\
(13.10)\end{array}$ & $\begin{array}{l}-0.097^{* *} \\
(7.25)\end{array}$ & $\begin{array}{c}-0.079 * * \\
(2.72)\end{array}$ \\
\hline Ind5 & $\begin{array}{c}-0.133^{* *} \\
(7.19)\end{array}$ & $\begin{array}{c}-0.107 * * \\
(5.57)\end{array}$ & $\begin{array}{r}-0.019 \\
(0.27)\end{array}$ & $\begin{array}{c}-0.071^{* *} \\
(6.06)\end{array}$ & $\begin{array}{c}-0.039 * * \\
(2.93)\end{array}$ & $\begin{array}{r}-0.051 \\
(1.68)\end{array}$ \\
\hline Ind6 & $\begin{array}{l}-0.212 * * \\
(11.63)\end{array}$ & $\begin{array}{l}-0.202^{* *} \\
(10.76)\end{array}$ & $\begin{array}{r}-0.135 \\
(1.85)\end{array}$ & $\begin{array}{c}-0.121^{* *} \\
(8.92)\end{array}$ & $\begin{array}{c}-0.073^{* *} \\
(4.69)\end{array}$ & $\begin{array}{c}-0.146^{* *} \\
(4.25)\end{array}$ \\
\hline Ind 7 & $\begin{array}{l}-0.078^{* *} \\
(4.28)\end{array}$ & $\begin{array}{c}-0.058 * * \\
(3.06)\end{array}$ & $\begin{array}{c}0.062 \\
(0.85)\end{array}$ & $\begin{array}{l}0.084 * * \\
(6.75)\end{array}$ & $\begin{array}{l}0.113^{* *} \\
(7.73)\end{array}$ & $\begin{array}{l}0.173 * * \\
(5.80)\end{array}$ \\
\hline Ind8 & $\begin{array}{c}-0.077^{* *} \\
(4.09)\end{array}$ & $\begin{array}{c}-0.057^{* *} \\
(2.91)\end{array}$ & $\begin{array}{r}-0.001 \\
(0.02)\end{array}$ & $\begin{array}{r}-0.011 \\
(0.91)\end{array}$ & $\begin{array}{c}0.008 \\
(0.58)\end{array}$ & $\begin{array}{r}0.039 \\
(1.31)\end{array}$ \\
\hline$\underset{N}{\operatorname{Adj}} R^{2}$ & $\begin{array}{r}0.675 \\
43987\end{array}$ & $\begin{array}{c}0.590 \\
31755\end{array}$ & $\begin{array}{r}0.541 \\
12232\end{array}$ & $\begin{array}{c}0.719 \\
58220\end{array}$ & $\begin{array}{c}0.627 \\
36834\end{array}$ & $\begin{array}{r}0.575 \\
21386\end{array}$ \\
\hline
\end{tabular}

Note: ${ }^{*}$ Statistically significant at the 0.05 level; ${ }^{* *}$ at the 0.01 level (two tailed test).

TABLE 5

Decomposimon of INequality, LeVel and Changes: 1986-93

\begin{tabular}{|c|c|c|c|c|c|c|c|c|c|c|c|c|}
\hline & \multicolumn{6}{|c|}{ Level } & \multicolumn{6}{|c|}{$\begin{array}{c}\text { \% Change in Inequality of Loz-Earaines: } \\
\text { Explained by Variable: }\end{array}$} \\
\hline & \multicolumn{3}{|c|}{1986} & \multicolumn{3}{|c|}{1993} & \multicolumn{3}{|c|}{ Gini } & \multicolumn{3}{|c|}{ Log-Variance } \\
\hline & $\begin{array}{l}\text { (1) } \\
\text { All }\end{array}$ & $\begin{array}{c}(2) \\
\text { Men }\end{array}$ & $\begin{array}{c}\text { (3) } \\
\text { women }\end{array}$ & $\begin{array}{l}\text { (4) } \\
\text { All }\end{array}$ & $\begin{array}{c}(5) \\
\text { Men }\end{array}$ & $\begin{array}{c}(6) \\
\text { Women }\end{array}$ & $\begin{array}{l}\text { (7) } \\
\text { All }\end{array}$ & $\begin{array}{c}(8) \\
\text { Men }\end{array}$ & $\begin{array}{c}(9) \\
\text { Women }\end{array}$ & $\begin{array}{l}(10) \\
\text { All }\end{array}$ & $\begin{array}{l}(11) \\
\text { Men }\end{array}$ & $\begin{array}{c}\text { (12) } \\
\text { Women }\end{array}$ \\
\hline Education & 0.139 & 0.160 & 0.117 & 0.079 & 0.077 & 0.086 & 48 & 59 & -8820 & 33 & 38 & 220 \\
\hline Married & 0.031 & 0.035 & 0.000 & 0.021 & 0.029 & 0.001 & 9 & T & 292 & 6 & 5 & -7 \\
\hline Union & 0.002 & 0.002 & 0.004 & 0.014 & 0.011 & 0.025 & -6 & -5 & 5981 & -3 & -2 & -140 \\
\hline Female & 0.134 & & & 0.141 & & & 9 & & & 11 & & \\
\hline $\begin{array}{l}\text { Log-bours } \\
\text { Potential }\end{array}$ & -0.013 & -0.009 & -0.019 & 0.001 & -0.004 & 0.007 & -9 & -3 & 7380 & -6 & -2 & -176 \\
\hline Experience & 0.093 & 0.088 & 0.027 & 0.062 & 0.074 & 0.018 & 27 & 16 & -2417 & 19 & 13 & 60 \\
\hline Tenure & 0.154 & 0.149 & 0.173 & 0.218 & 0.226 & 0.244 & -21 & -25 & 20049 & -5 & -5 & -454 \\
\hline Size & 0.009 & 0.029 & 0.007 & 0.019 & 0.032 & 0.012 & 5 & 1 & 1639 & -2 & 2 & -38 \\
\hline Region & 0.008 & 0.010 & 0.012 & 0.010 & 0.009 & 0.018 & 0 & $i$ & 1852 & 0 & 1 & -42 \\
\hline Occupation & 0.112 & 0.125 & 0.188 & 0.095 & 0.121 & 0.107 & 21 & is & -19356 & 17 & 14 & 567 \\
\hline Industry & 0.049 & 0.038 & 0.068 & -0.095 & 0.016 & 0.024 & 25 & 15 & -10518 & 16 & 10 & 305 \\
\hline Residual & 0.281 & 0.373 & 0.425 & 0.325 & 0.410 & 0.458 & 4 & 18 & 9366 & 15 & 27 & -177 \\
\hline Sum & 1.000 & 1.000 & 1.000 & 1.000 & 1.000 & 1.000 & 101 & 101 & 101 & 101 & 101 & 100 \\
\hline
\end{tabular}


TABLE 6

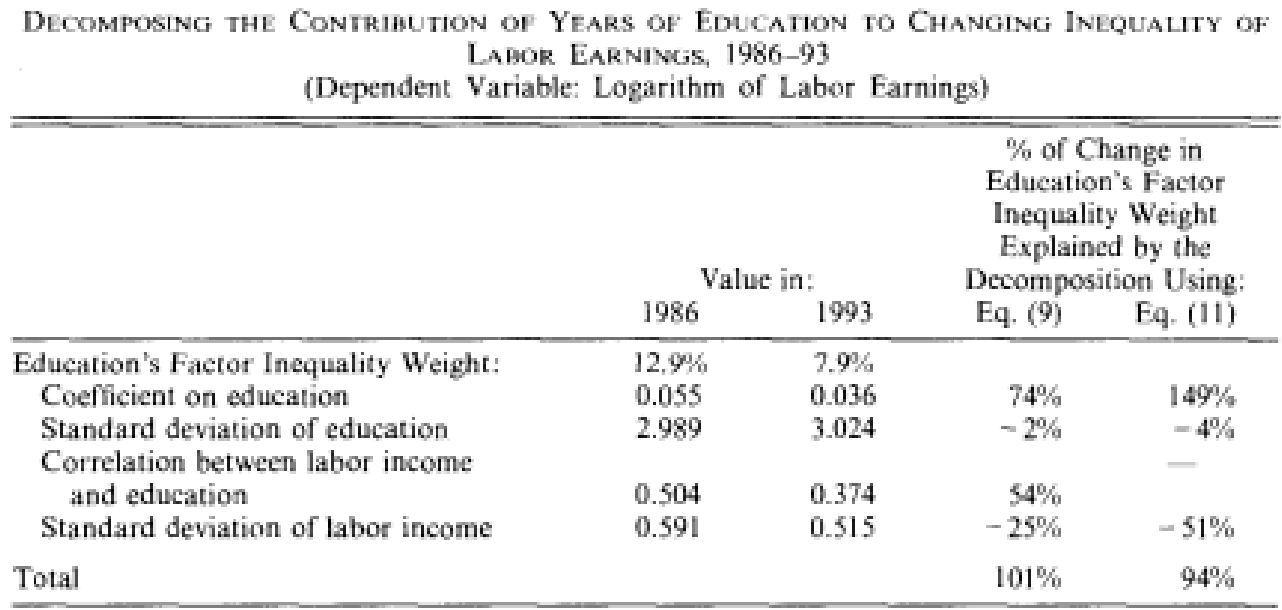

Finally, there is one variable, job tenure, that makes a sizeable negative contribution to explaining falling labor income inequality. The reasons that job tenure contributed to rising inequality are: (i) the regression results indicate that the job tenure effects steepened between 1986 and 1993; (ii) the inequality of years of tenure, as measured by the variance, increased substantially; and (iii) the correlation between job tenure and labor income increased.

\section{Separate Earnings Determinants for Men and Women}

In the preceding analysis, gender was found to be one of the leading determinants of labor earnings in Korea. Korean women suffer from gender discrimination in two ways: (i) some jobs that are open to men are not open to women ("occupational discrimination") and (ii) within jobs, women get paid less in Korea than men do ("wage discrimination"). An estimated 33-43 percent of the gender differential in earnings is attributed to one of these two forms of labor market discrimination (Bai and Cho, 1995; Rodgers, 1998).

Due to these differences, we also performed separate analyses for men and women. The first finding is that labor income inequality decreased between 1986 and 1993 only for men (Table 7). When we estimated separate earnings equations

TABLE 7

Changing Labor Income Inequality for Men AND WOMEN IN KOREA, 1986-93

\begin{tabular}{llcc}
\hline \hline \multirow{2}{*}{ Men } & & 1986 & 1993 \\
& Gini Cocfficicnt & 0.3034 & 0.2545 \\
\multirow{2}{*}{ Women } & Log Variance & 0.2885 & 0.2098 \\
& Gini Coefficient & 0.2391 & 0.2392 \\
& Log Variance & 0.1648 & 0.1624 \\
\hline
\end{tabular}

Source: Authors' calculations from OWS tapes.

for men and women (Table 4) and performed separate decompositions for men and women (Table 5), we found the following. 
1. For both men and women, nearly all of the variables included in the regressions are highly statistically significant with the expected signs. For men, the variables that were found to be important in explaining the level of labor income inequality in 1993 were, in order of importance, job tenure, occupation, years of education, and potential experience. For women, the three most important variables were the same ones: job tenure, occupation, and years of education. All other variables were unimportant for both men and women. Thus, the only important qualitative difference between men and women in earnings determinants was the importance of potential experience for men and its unimportance for women.

2. When it comes to explaining the changes between 1986 and 1993, the most important variables contributing to the fall in labor income inequality among men were, first, years of education; then potential experience, occupation, and industry, with approximately equal importance; and lastly, marital status. Among women, the determinants were quite similar: those factors contributing to falling inequality among women were, in order of importance, occupation, industry, and years of education, while those that contributed to rising inequality among women included job tenure, log hours, and union.

3. Finally, breaking down the effect of education, which was the leading explanatory factor for men and one of the leading factors for women, the decomposition reveals a marked difference between the two genders. For men, the returns to education fell over tune (the regression coefficient on the education variable for men declined from 0.059 in 1986 to 0.037 in 1993), but for women, education's coefficient was essentially unchanged (0.0404 in 1986, 0.0400 in 1993). This means that while the coefficients effect may have been important for men, it would not be expected to have been important for women. Indeed, the last stage decomposition results show exactly that: for men, the coefficients effect and the correlation effect are about of equal importance (64 percent and 58 percent respectively) while the standard deviation effect explains just 3 percent. For women, the pattern is entirely different: the correlation effect more than explains the total $(+123$ percent), while the coefficients effect is tiny $(+3$ percent $)$ and the standard deviation effect is negative ( -25 percent - negative, because years of education came to be more unequally distributed among women).

\section{Accounting for Falling Inequality in Earlier Years}

To see whether the same factors had been responsible for the decrease in inequality in Korea in earlier years, we repeated the analysis for the changes between 1981 and 1986 and between 1976 and 1981. In each case, the regression specifications were adjusted so that the exact same explanatory variables appeared in the base and comparison years. The decomposition results are reported in Table 8; regression results are omitted for space reasons. 
TABLE 8

DECOMPOSITION OF INEQUALITY CHANGES FOR 1981-86, 1976-81

\begin{tabular}{|c|c|c|c|c|c|c|c|c|}
\hline & \multicolumn{4}{|c|}{$1981-86$} & \multicolumn{4}{|c|}{$1976-81$} \\
\hline & \multicolumn{2}{|c|}{ Level } & \multicolumn{2}{|c|}{$\begin{array}{l}\% \text { Change in } \\
\text { Ineq. of } \\
\text { Log-Earnings: } \\
\text { Explained by } \\
\text { Variable: }\end{array}$} & \multicolumn{2}{|c|}{ Level } & \multicolumn{2}{|c|}{$\begin{array}{l}\% \text { Change in } \\
\text { Ineq. of } \\
\text { Log-Earnings: } \\
\text { Explained by } \\
\text { Variable: }\end{array}$} \\
\hline & 1981 & 1986 & Gini & $\begin{array}{c}\text { Log- } \\
\text { Variance }\end{array}$ & 1976 & 1981 & Gini & $\begin{array}{c}\text { Log- } \\
\text { Variance }\end{array}$ \\
\hline Education & 0.1651 & 0.1415 & 48 & 35 & 0.1835 & 0.1766 & 27 & 24 \\
\hline $\begin{array}{l}\text { Tenure and } \\
\text { experience }\end{array}$ & 0.1725 & 0.2299 & -60 & -27 & 0.1486 & 0.1826 & -29 & -14 \\
\hline Married & 0.0806 & 0.0657 & 28 & 20 & 0.0760 & 0.0796 & 3 & 5 \\
\hline Gender & 0.1548 & 0.1473 & 26 & 21 & 0.1043 & 0.1486 & -47 & -27 \\
\hline Firm Size & 0.0059 & 0.0099 & -5 & -3 & 0.0054 & 0.0003 & 7 & 5 \\
\hline Hours & -0.0143 & -0.0122 & -4 & -3 & -0.0063 & -0.0161 & 12 & 8 \\
\hline Industry & 0.0469 & 0.0497 & 1 & 3 & 0.0326 & 0.0421 & -9 & -5 \\
\hline Region & 0.0087 & 0.0092 & 0 & 0 & 0.0018 & 0.0086 & -9 & -6 \\
\hline Occupation & 0.0957 & 0.1022 & 1 & 5 & 0.1070 & 0.0708 & 58 & 41 \\
\hline Residual & 0.2841 & 0.2563 & 66 & 50 & 0.3475 & 0.3067 & 88 & 69 \\
\hline Sum & 1.000 & 1.000 & 101 & 100 & 1.000 & 1.000 & 101 & 101 \\
\hline
\end{tabular}

In both 1981 and 1986, the important variables determining the levels of inequality were tenure and experience, education, gender, and occupation - exactly the same variables that were most important in 1993. As for the changes in inequality between 1981 and 1986, education was the most important factor, followed by marital status and gender. Earlier, we reported that education was also the most important variable accounting for the fall in inequality between 1986 and 1993.

Performing similar calculations for 1976 to 1981, the most important factors explaining the levels of inequality in those years were education, tenure and experience, and gender-again, the same factors. Changes in inequality were accounted for primarily by occupation, then education, in those years.

\section{Conclusions}

This study has sought to understand what accounts for Korea's falling labor income inequality in the course of its rapid economic growth. We have reached the following empirical conclusions.

First, the most important factors explaining the level of income inequality in 1993 were job tenure and potential experience, gender, occupation, and years of education. These same variables were also found to be the most important ones in 1986, 1981, and 1976 as well. Furthermore, those variables that were found to be unimportant in one year were unimportant throughout - these include union, marital status, hours, firm size, region, and industry. 
Second, the variables of greatest importance in explaining the changes in inequality in Korea were, for the 1986-93 period, years of education, potential experience, industry, and occupation; for the 1981-86 period, education, marital status, and gender; and for the 1976-81 period, occupation followed by education. Note the recurring prominence of education in each year.

Third, to see why education contributed as much as it did to falling labor income inequality, a further decomposition was performed. The principal reason is a fall in the coefficient on education in the earnings function. A secondary factor is that education became less correlated with earnings than it had been. Education did not contribute to falling income inequality because of an equalization of educational attainments - in fact, educational attainments became slightly more unequal from 1986 to 93 in Korea.

Finally, a gender disaggregation also proved insightful. Labor income inequality fell for men during the 1986-93 period but not for women. Also, during 1986-93, the returns to education fell for men but not for women. These and other gender differences call for further investigation into the workings of male and female labor markets in Korea, since they appear to work quite differently. 


\section{References}

Bai, M. K. and W. H. Cho, Women's Wages and Employment in Korea, Seoul National University Press, Seoul, 1995.

Choi, K.-S., The Impact of Shifts in Supply of College Graduates: Repercussion of Educational Reform in Korea, Economics of Education Review, 1996.

Choo, H.-C., Income Distribution and Distributive Equity in Korea, in L. B. Krause and F.-K. Park (eds.), Social Issues in Korea: Korean and American Perspectives, Korea Development Institute, Seoul, 1993.

Chu, Y.-P., Employment Expansion and Equitable Growth: Taiwan's Postwar Experience, Working Paper, Sun Yat-Sen Institute for Social Sciences and Philosophy, Academia Sinica, July 1997.

Deininger, K. and L. Squire, Measuring Income Inequality: A New Data-Base, World Bank Economic Review, September 1996.

Economic Planning Board, Social Indicators in Korea, annual.

Fields, G. S., Accounting for Income Inequality and Its Change, Cornell University, processed 1998.

Fields, G. S. and J. O'Hara Mitchell, Changing Income Inequality in Taiwan: A Decomposition Analysis, in G. Saxonhouse and T. N. Srinivasan (eds.), Development, Duality, and the International Regime: Essays in Honor of Gustav Ranis, University of Michigan Press, Ann Arbor, 1999.

Haggard, S., R. N. Cooper, S. Collins, C. Kim, and S.-T. Ro, Macroeconomic Policy and Adjustment in Korea, 1970-90, Harvard Institute for International Development: Cambridge, 1995.

Halvorsen, R. and R. Palmquist, The Interpretation of Dummy Variables in Semilogarithmic Equations, American Economic Review, 1980.

Ito, T. and A. Krueger (eds.), Growth Theories in Light of the East Asian Experience, University of Chicago Press for the National Bureau of Economic Research, Chicago, 1995.

Jung, J. H., Personal Income Distribution in Korea, 1963-86: A Human Capital Approach, Journal of Asian Economics, 1992.

Kim, D.-I. and R. Topel, Labor Markets and Economic Growth: Lessons from Korea's Industrialization, 1970-90, in R. Freeman and L. Katz (eds.), Differences and Changes in Wage Structures, University of Chicago Press, Chicago, 1995.

Kim, D.-M. and K.-S. Ahn, Survey of National Line of Thinking About Income Distribution and Its Determinants and the Problem of Distribution, Choong-Ang University, Seoul, 1987. 
Kim, D.-M. and G. Yoo, Analysis of Wage Differentials by Firm Size in Korea, Korean Journal of Labor Economics, 1996.

Leipziger, D. M., Lessons from East Asia, University of Michigan Press, Ann Arbor, 1997.

Ministry of Labor, Report on Occupational Wage Survey, annual.

National Statistical Office, Social Indicators in Korea, annual.

Park, S.-L, The Role of the State in Industrial Relations: the Case of Korea, Comparative Labor Law Journal Spring 1993.

Park, Y.-B. (ed.), Labor in Korea, Korea Labor Institute, Seoul, 1993.

Rodgers, Yana van der Meulen, A Reversal of Fortune for Korean Women: Explaining the 1983 Upward Turn in Relative Earnings, Economic Development and Cultural Change, July 1998.

Schultz, T. P., Income Inequality in Taiwan 1976-95: Changing Family Composition, Aging and Female Labor Force Participation, in G. Ranis, S.-C. Hu, and Y.-P. Chu (eds.), The Political Economy of Taiwan's Development into the 21st Century, Edward Elgar, Northampton, MA, 1999.

Shorrocks, A. F., Inequality Decomposition by Factor Components, Econometrica, January 1982.

Suh, S.-M., The Economy in Historical Perspective, in V. Corbo and S.-M. Suh (eds.), Structural Adjustment in a Newly Industrialized Country, Washington, DC, World Bank, 1992.

World Bank, The East Asian Miracle, Washington, DC, 1993.

Young, A., The Tyranny of Numbers: Confronting the Statistical Realities of the East Asian Growth Experience, Quarterly Journal of Economics, August 1994. 